\title{
Epidemiology is more than discourse: critical thoughts from Latin America
}

The essay by Avilés ${ }^{1}$ is a powerful and well stated piece of work. It will certainly become an important reference regarding the misuse of epidemiology in the context of international politics. There is wide evidence concerning the political uses of science and technology as a tool for colonialism and economic domination..$^{2}$ Indeed, the health field has been one of the most affected by such processes, with its research agenda and priorities for action defined by central countries. ${ }^{3}$ In the past, yellow fever and malaria control, nowadays the so called emergent and re-emergent diseases, are good examples of this kind. ${ }^{4}$

The paper ${ }^{1}$ consists of an analysis of the ideological discourse that lies beneath the Epidemiological Profile of El Salvador, a single author document sponsored by the United States Agency for International Development (USAID). Its major goal is the denunciation of epidemiological transition theory as a offspring of modernisation ideology, ${ }^{5}$ a doctrine that supports the action of international agencies. Avilés' critique of epi-transition theory is put forward on five grounds: legitimisation tool; political dissimulation; reality homogenisation; defence against domination challenging; source of naturalisation of epidemiological processes. Although such criticism sounds reasonable and fair, a key issue is not touched. It is the fact that epi-transition theory is anything but a scientific theory. Indeed it lacks all epistemological features that make any systematic discourse a theoretical framework, namely a structure of explanation that delves into the determinants of a given concrete problem. ${ }^{6}$

In addition, Avilés' paper misses the opportunity of making a fundamental point. As one of us has indicated previously, ${ }^{7}$ even before Omran's seminal paper ${ }^{8}$ the roots of epi-transition theory were well grounded with neoevolutionary approaches of modernisation ${ }^{5}$ and in the discourse of intellectuals connected to USAID. ${ }^{9}$ The epi-transition model adopted a single, evolutionist and ethnocentric view of social change in the "peripheral world". This is the framework behind the notion that improvements in the health situation result in great measure from the incorporation of new technologies, brought about by processes isolated from the social, economic and political context. It does not emphasise that the Western development model was the result of an industrial revolution originated from inside a few countries, while in those presented today as "developing" ones the "revolution" was imposed from outside. Such countries have been mere recipients of technologies produced or at least conceived in industrialised countries. As a consequence, ideas originated in peripheral countries usually do not receive the deserved attention in the global debate and are seen with no confidence while, in fact, they have potential to contribute to rebuild the local patterns of development.

The essay in point is a case study based upon one single report related to a specific country in a given context. The author's intention is to disclose "the ways development institutions influence the practice of epidemiology". Unfortunately, such ambition is clearly beyond the reach of the paper. To take it as a general illustration of the weaknesses and strengths of epidemiology as a science and a social practice in the developing world is perhaps too much to demand from it. Epidemiology as a scientific discipline and a body of knowledge cannot be judged through the analysis of a report based on a straightforward applica- tion of elementary quantitative methodology and a clearly biased framework.

The most intriguing aspect of Avilés' paper is that despite being a harsh, powerful disclosure of imperialism, it is not capable of escaping the trap of bringing a perspective that, although progressive in intent, is still alien to the context under analysis. It uses a US left wing perspective that does not take into account intellectual efforts of Latin American scholars. This ends up reinforcing one of the most effective ideological devices of the North-South domination: to superimpose their voices over the voices of those who are oppressed.

Currently, in Latin America, epidemiology has evolved into a rich and diverse network devoted to the analysis of health and its determinants. Our epidemiology has been directed towards the construction of theoretical frameworks that include the health-disease-care processes as part of the societal organisation. Being not just an intellectual endeavour, it has reassured historical compromises through the denunciation and opposition to all forms of social or health inequalities towards the construction of equity oriented health policies. ${ }^{10}{ }^{11}$ Precisely for the reasons explored by Avilés' essay, such efforts have only been marginally considered in the Anglo-Saxon epidemiological literature. In addition to the work done in research topics such as: infectious disease, maternal and child health, mental health, occupational and environmental health, etc, epidemiologists in Latin America have developed a sophisticated discussion of questions on the epistemology of epidemiology and development of complex causality models. Since the 1970 s, but especially in the past decade, our epidemiologists have touched a number of critical contemporary issues, ranging from more theoretical discussions about the "macro-micro" and "socio-biological" debates, to methodological contributions developed around nonempiricist logic. ${ }^{12-15}$ We have been always critical of the epidemiology overemphasis on mathematical formal thinking and its failure in dealing with the challenges of community geared research.

Such literature is widely available in Portuguese and Spanish, but several scholars have overcome the publication barriers making their way to English written publications. ${ }^{16}$ Despite its virtues and value, particularly for calling the attention to the political uses of epidemiological jargon for continuing the domination of a country over the other, Avilés' paper misses a chance for bridging the gap between epidemiologists from Latin America and those from North America and Europe who are sincerely interested in transforming such state of affairs. In addition, for epidemiology, a clear disciplinary advantage shall be gained when critical scholars of both sides of the Rio Grande and of the Atlantic Ocean establish collaborative efforts in the development of a conscientious health science, effectively on the side of humanity.

MAURICIO L BARRETO Instituto de Saude Coletiva, Universidade Federal da Bahia, Rua Padre Feijó, 29, Salvador-Bahia, 40.110-170 Brazil

NAOMAR DE ALMEIDA-FILHO Instituto de Saúde Coletiva, Universidade Federal da Bahia

JAIME BREILH

Centro de Estudios y Asesoría en Salud, Asturias N 2402 y $G$ de Vera (La Floresta), Quito, Ecuador

Correspondence to: Dr Barreto (mauricio@ufba.br) 
1 Avilés LA. Epidemiology as discourse: the politics of development institutions in the Epidemiological Profile of El Salvador. F Epidemiol Community Health 2001;55:164-71.

2 Blissett M. Politics in science. Boston: Little, Brown, 1972.

3 Watts S. Epidemics and history: disease, power and imperialism. New Haven: Yale University Press, 1995.

4 Barreto ML. Emergência e 'permanência' das doenças infecciosas: implicações para a saúde pública e para a pesquisa. Médicos 1998;3:18-25,

5 Rostow WW. The stages of economic growth: a non-communist manifesto. New York: Cambridge University Press, 1991

6 Salmon W. Scientific explanation and the causal structure of the world. Princeton: Princeton University Press, 1984.

7 Barreto ML, Carmo EH, Noronha CV, et al. Mudanças dos padrões de morbi-mortalidade: uma revisão crítica das abordagens epidemiológicas. Physis - Revista de Saúde Coletiva 1993;3:127-46.

8 Omran AR. The epidemiologic transition theory: a theory of the epidemiology of population change. Milbank Mem Fund $Q$ 1971;49:509-83.
9 Frederiksen $\mathrm{H}$. Feedbacks in economic and demographic transition. Science 1969;166:837-47.

10 Barata RB, Barreto ML. Algumas questões sobre o desenvolvimento da epidemiologia na América Latina. Ciência e Saúde Coletiva 1996;1:70-9.

11 Barreto ML. Por uma epidemiologia de saúde coletiva. Revista Brasileira de Epidemiologia 1998;1:104-30.

2 Breilh J. Epidemiologia: Economia, Medicina y Politica . Mexico: Fontamara, 1989.

13 Almeida Filho N. Epidemiología Sin Números. Buenos Aires: Paltex/OPS, 1992.

14 Almeida Filho N. La Ciencia Tímida-Ensayos de deconstrucción de la Epidemiología. Buenos Aires: Lugar Editorial, 2000.

15 Ayres JR. Sobre o Risco-Para compreender a Epidemiología. São Paulo: Hucitec, 1997.

16 Pellegrini-Filho A, Goldbaum M. Production of scientific articles on health in six Latin American countries, 1983-1992. Pan Am f Public Health 1997; 2:121-32. 